\title{
Problem Solving Skills Developments Through Entrepreneurship
}

\author{
W Mohd Rashid W Ahmad* \\ Faculty of Technical and Vocational Education, University Tun Hussein Onn Malaysia, 86400 Parit Raja, Batu Pahat, Johor, Malaysia
}

\author{
Abidah Ainah Mohamed \\ Faculty of Technical and Vocational Education, University Tun Hussein Onn Malaysia, 86400 Parit Raja, Batu Pahat, Johor, Malaysia
}

Fatimah Mustaffa

Department of Professionalism Research and Innovation, Malay Women Teachers Education Campus, Jalan Maktab 75400 Durian Daun, Melaka, Malaysia

\begin{abstract}
The unemployment problem among graduates is associated with issues of shortage and weakness of graduates issued by Higher Education Institutions (IPTs). The unemployment caused by lack of soft skills (KI) includes problem solving skills. This study aims to identify the application of problem solving skills through entrepreneurship cocurriculum among students at University Tun Hussein Onn Malaysia (UTHM). The total population involved is 35 students who are involved in entrepreneurship co-curriculum at UTHM. The researchers used all the population as a sample of the study. Researchers used document analysis instruments, observations, analysis of interview transcripts and questionnaire analysis. The study was conducted in mixed form. That is a combination of qualitative and quantitative studies. This qualitative study consists of document analysis, observation and interview. The results of the questionnaire were analyzed using the Statistical Packages for Social Science (SPSS) Version 16. The results of this study found that there was an application in problem solving skills in entrepreneurship co-curriculum.

Keywords: Co-curriculum; Soft skills; Problem solving skills.
\end{abstract}

(9) (1) CC BY: Creative Commons Attribution License 4.0

\section{Introduction}

Malaysia is a developing country and needs to compete in a global era to achieve a developed nation level ahead of Vision 2020. Knowledge workers or workers are the top priority among employers to drive business in tandem with economic growth (Zakariya, 2003). Employees who are required to meet the needs of employers and the industrial sector are not only academically and technically qualified but include the mastery of other skills such as problem solving skills, critical thinking skills and creative, technological use and communication skills.

The statement by AC Nielsen (ACNielsen, 2000) found that employers are more concerned with creative skills, natural abilities, communication, problem solving and group collaboration in finding potential employees. While the quality of graduates being released from universities is increasingly being said, the question of marketability in the marketplace needs to be mastered in soft skills. The impact of global developments on the industry and the sectors of employment reflects the increasing demand for labor that is not only qualified and knowledgeable, but the mastery of employment skills and the use of information and communications technology is emphasized (Mohamad et al., 2009). Hence, with the upsurge in demand for highly knowledgeable and highly skilled workforce affects the increased competition among graduates to obtain a suitable place in the employment sector. The impact of competition will bring unemployment problems among graduates.

The unemployment issues among these graduates are attributed to the weakness of graduates issued from institutions of higher learning. They are said to be incapable of thinking critically, lack of problem-solving skills, lack of communication skills and group work, lack of skills using ICT facilities and poor English. (Pauw and Osthuizen, 2008) argues that the cause of graduates is unemployed due to lack of soft skills including problem solving skills. As such, most employers today are more focused on experienced workers than just graduating graduates. However, employers are more likely to find employees who possess and master a variety of skills. An important goal in Malaysian education is the development of human capital in providing skilled workforce and able to face the challenges of the future Buntat et al. (2008). Therefore, thinking skills as an intellectual process involving analysis, application, concept, synthesis and evaluating information gathered through experience and communication. In entrepreneurship co-curricular, students are also exposed to activities that are team-based in solving problems. Therefore, as one of the ways to assist students is to improve social skills through involvement in clubs, associations and co-curriculum.

\subsection{Research Objective}

The objective of this study is to identify the application of problem solving skills through entrepreneurship cocurriculum among UTHM students. 


\section{Literature Review}

The issue of graduates especially the issue of unemployment among local graduates has been a hot issue being discussed. Among the key factors why local graduates failed to get a job because of their weaknesses to communicate well, especially in English. Therefore, the employer is seen as a party that plays an important role in emphasizing the importance of the purpose and the form of skills characterized as soft skills. This is because soft skills are a necessary form of skills in the development of human capital to meet the market economy that is knowledge-based especially in the 21st century. Among the elements of soft skills that the students need to master is problem solving skills. Problem solving skills can be applied in a variety of co-curricular activities, especially entrepreneurship co-curriculum. In entrepreneurship co-curriculum, students are exposed in ways to solve problems related to business. Empowerment of co-curricular courses in the system of study should be emphasized accordingly. Co-curricular courses credited as a condition for graduation have been introduced at the institute of higher learning.

\section{Methodology}

To answer the objective of the study, identifying the application of problem solving skills through entrepreneurship co-curriculum among students in UTHM, researchers used document analysis tools, observations, analysis of interview transcripts and questionnaire analysis. This study was conducted in mixed method. That is a combination of qualitative and quantitative studies. This qualitative study consists of document analysis, observation and interview. Quantitative research consists of surveys survey by distributing questionnaires.

\section{Results and Findings}

The first instrument used to analyze is the analysis of the document. Document analysis is a breakdown of the content analysis research method that is an objective description of the communication message that has been printed, published or described. The document in this study refers to the subject syllabus (RPP) of entrepreneurship co-curriculum. The silibus is analyzed based on whether or not the elements of problem solving skills in the syllabus of entrepreneurship co-curricular subjects for a semester. Analysis is done by assessing each week the syllabus of teaching that should be taught by the lecturer to the students of the curriculum of entrepreneurship. The teaching silibus for entrepreneurship co-curricular subjects during the 14 weeks of this activity is being implemented. Starting from the first week to week 14 this activity is implemented, the entrepreneurial co-curricular Learning and Teaching Plan (RPP) taught to students about the introduction of entrepreneurship, emphasizes on the introduction of entrepreneurship, business plan, planning to carry out business projects, administration and marketing management and alternative business plans. Based on the RPP, it is also found that the aim of this subject is to produce graduates with soft skills in entrepreneurship, especially in terms of entrepreneurial knowledge, entrepreneurship skills and business base that can be applied in the career development. Therefore, based on the analysis shows that the application of problem solving skills in the analysis of documents involving the RPP proforma to the entrepreneurship co-curricular course.

The second instrument is the observation checklist. The observation checklist analysis is based on the frequency recorded on each item in the observation checklist during the six observations made. In addition, researchers have taken pictures of each behavior that has the characteristics of problem solving skills through entrepreneurship cocurriculum. For this purpose, the researchers conducted six observations on each Wednesday. Checklist item content covers all elements of problem solving skills such as the ability to identify and analyze problems, collect data and decision-making capabilities, ability to identify problem solving and the ability to execute decisions. Researchers conclude that entrepreneurship co-curriculum has indeed been applied in the element of problem solving skills in this UTHM activity. Based on an analysis of the observation checklist recorded from the 15 checklist items over the sixtime observation included additional projects conducted by students.

The third instrument used to answer the question of the first study was an interview transcript. Analysis of interview transcripts is made to see whether or not the application of problem element solving skills through student involvement through entrepreneurship co-curriculum. To achieve the objective of this study, the researcher interviewed the entrepreneurial co-curriculum student at UTHM to find out more about the application of problem solving skills through entrepreneurship co-curriculum at UTHM. The interviews have been structured semistructured interviews. After the interview was conducted, the researcher copied the interview text to be analyzed.

Based on the analysis of interview transcripts, all respondents stated that there was an application of the problem solving skills in entrepreneurship co-curricular activities. The first respondent stated that the problem solving skills in this entrepreneurial co-curriculum existed and helped in solving the problem. Similarly, the second respondent's opinion also states that problem solving skills through this entrepreneurship co-curriculum is still being applied.

Table-1. The Mean Score Analysis, The Frequency And The Percentage Of Applying For Element Item Problem Solving Skills

\begin{tabular}{|c|c|c|c|c|c|c|c|c|c|}
\hline Item & $\begin{array}{|ll|}\begin{array}{l}\text { Ability to } \\
\text { and } \\
\text { problems }\end{array} & \begin{array}{l}\text { identify } \\
\text { analyze }\end{array} \\
\end{array}$ & & 1 & 2 & 3 & 4 & 5 & $\begin{array}{l}\text { Mean } \\
\text { score }\end{array}$ & $\begin{array}{l}\text { Interpretation } \\
\text { mean }\end{array}$ \\
\hline B1 & $\begin{array}{l}\text { I am able to express } \\
\text { the problem clearly }\end{array}$ & $\begin{array}{l}\mathrm{F} \\
\%\end{array}$ & - & - & $\begin{array}{l}2 \\
5.7 \\
\end{array}$ & $\begin{array}{l}28 \\
80 \\
\end{array}$ & $\begin{array}{l}5 \\
14.3 \\
\end{array}$ & 4.09 & High \\
\hline B2 & $\begin{array}{l}\text { I understand the } \\
\text { problems that occur in }\end{array}$ & $\%$ & - & - & 4 & 27 & 4 & 4.00 & High \\
\hline
\end{tabular}




\begin{tabular}{l|lr|l|l|l|l|l|l|l|l}
\hline & \multicolumn{2}{|l|}{$\begin{array}{l}\text { the entrepreneurship } \\
\text { co-curriculum. }\end{array}$} & F & - & - & 11.4 & 77.1 & 11.4 & & \\
\hline B3 & $\begin{array}{l}\text { I'm patient when } \\
\text { dealing } \\
\text { problems. }\end{array}$ & with & F & - & - & 4 & 23 & 8 & $\mathbf{4 1}$ & High \\
\hline
\end{tabular}

The fourth instrument used is the questionnaire. Questionnaires were analyzed based on the percentage and the highest frequency of each item for problem solving skills. Part B of the questionnaire is a set of items on the application of problem solving skills through entrepreneurship co-curriculum. The findings of table 1 show that the overall mean score recorded in this item is 4.09. This demonstrates the awareness of applying problem solving skills is at high level. On the element of ability to identify and analyze problems, item B 1 shows the highest frequency at scale applied to 80.0 percent. The highest frequency in item B2 is on the scale applied with $77.1 \%$ with 27 number of frequencies. For item B3, the highest percentage is on the applied scale of $65.7 \%$ with frequency of 23 . Based on the above questionnaire analysis, the researcher concludes that there is an application of the element of ability to identify and analyze the problem.

Table-2. The Mean Score Analysis, The Frequency And The Percentage Of Applying For Element Item Problem Solving Skills

\begin{tabular}{|c|c|c|c|c|c|c|c|c|c|}
\hline Item & $\begin{array}{|lr|}\text { Collect } & \text { data } \quad \text { and } \\
\text { decision } & \text { making } \\
\text { abilities } & \\
\end{array}$ & & 1 & 2 & 3 & 4 & 5 & $\begin{array}{l}\text { Mean } \\
\text { score }\end{array}$ & $\begin{array}{l}\text { Interpretation } \\
\text { mean }\end{array}$ \\
\hline B4 & $\begin{array}{l}\text { I am able to analyze } \\
\text { the problem critically. }\end{array}$ & $\begin{array}{l}\mathrm{F} \\
\% \\
\end{array}$ & - & $\begin{array}{l}1 \\
2.9 \\
\end{array}$ & $\begin{array}{l}9 \\
25.7 \\
\end{array}$ & $\begin{array}{l}21 \\
60.0 \\
\end{array}$ & $\begin{array}{l}4 \\
11.4 \\
\end{array}$ & 3.80 & High \\
\hline B5 & $\begin{array}{l}\text { I made a neat plan in } \\
\text { the process of solving } \\
\text { the problem. }\end{array}$ & $\begin{array}{l}\% \\
\mathrm{~F}\end{array}$ & - & - & $\begin{array}{l}9 \\
25.7\end{array}$ & $\begin{array}{l}20 \\
57.1\end{array}$ & $\begin{array}{l}6 \\
17.1\end{array}$ & 3.91 & High \\
\hline B6 & $\begin{array}{l}\text { I share information } \\
\text { when troubleshooting. }\end{array}$ & $\begin{array}{l}\% \\
\mathrm{~F}\end{array}$ & - & - & $\begin{array}{l}1 \\
2.9\end{array}$ & $\begin{array}{l}22 \\
62.9\end{array}$ & $\begin{array}{l}12 \\
34.3\end{array}$ & 4.31 & High \\
\hline
\end{tabular}

Refers to the the 2 second element collecting data and decision-making abilities. The highest frequency in item B4 is on the applied scale of $60.0 \%$ with 21 number of frequencies. For item B5, the highest percentage is on the applied scale of $57.1 \%$ with a frequency of 20 . The highest percentage for item B6 is $62.9 \%$ with a frequency of 22 at applied scale. The researcher concluded that there is an application of elements in collecting data and decisionmaking capabilities.

\begin{tabular}{|c|c|c|c|c|c|c|c|c|c|}
\hline Item & $\begin{array}{l}\text { Ability to identify } \\
\text { problem solving }\end{array}$ & & 1 & 2 & 3 & 4 & 5 & \begin{tabular}{|l} 
Mean \\
score
\end{tabular} & $\begin{array}{l}\text { Interpretation } \\
\text { mean }\end{array}$ \\
\hline B7 & $\begin{array}{l}\text { I act rationally when } \\
\text { evaluating something. }\end{array}$ & $\begin{array}{l}\mathrm{F} \\
\%\end{array}$ & - & - & $\begin{array}{l}4 \\
11.4 \\
\end{array}$ & $\begin{array}{l}21 \\
60.0 \\
\end{array}$ & $\begin{array}{l}10 \\
28.6 \\
\end{array}$ & 4.17 & High \\
\hline B8 & $\begin{array}{l}\text { I am able to identify } \\
\text { the need to make a } \\
\text { decision. }\end{array}$ & $\begin{array}{l}\% \\
\mathrm{~F}\end{array}$ & - & - & $\begin{array}{l}5 \\
14.3 \\
\end{array}$ & $\begin{array}{l}25 \\
71.4 \\
\end{array}$ & $\begin{array}{l}5 \\
14.3 \\
\end{array}$ & 4.00 & High \\
\hline B9 & $\begin{array}{l}\text { I am able to make an } \\
\text { assessment to solve } \\
\text { the problem. }\end{array}$ & $\begin{array}{l}\% \\
\mathrm{~F}\end{array}$ & - & - & $\begin{array}{l}5 \\
14.3 \\
\end{array}$ & $\begin{array}{l}24 \\
68.6 \\
\end{array}$ & $\begin{array}{l}6 \\
17.1 \\
\end{array}$ & 4.03 & High \\
\hline B10 & $\begin{array}{l}\text { I am able to find some } \\
\text { suitable ways to solve } \\
\text { the problem. }\end{array}$ & $\begin{array}{l}\mathrm{F} \\
\%\end{array}$ & - & $\begin{array}{l}1 \\
2.9 \\
\end{array}$ & $\begin{array}{l}3 \\
8.6 \\
\end{array}$ & $\begin{array}{l}25 \\
71.4\end{array}$ & $\begin{array}{l}6 \\
17.1 \\
\end{array}$ & 4.03 & High \\
\hline B11 & $\begin{array}{l}\text { I am able to make a } \\
\text { decision to solve the } \\
\text { problem. }\end{array}$ & $\begin{array}{l}\mathrm{F} \\
\% \\
\end{array}$ & - & - & $\begin{array}{l}3 \\
8.6 \\
\end{array}$ & $\begin{array}{l}25 \\
71.4 \\
\end{array}$ & $\begin{array}{l}7 \\
20.0 \\
\end{array}$ & 4.11 & High \\
\hline B12 & $\begin{array}{l}\text { I chose the best } \\
\text { alternative to solve the } \\
\text { problem. }\end{array}$ & $\begin{array}{l}\mathrm{F} \\
\%\end{array}$ & - & - & $\begin{array}{l}2 \\
5.7\end{array}$ & $\begin{array}{l}21 \\
60.0\end{array}$ & $\begin{array}{l}12 \\
34.2\end{array}$ & 4.29 & High \\
\hline
\end{tabular}

For the third element table 3 shows the ability to identify problem solving. For the highest percentage B7 items are on the applied scale of $60.0 \%$ with a frequency of 21 . Meanwhile, the highest percentage of item B8 is $71.4 \%$ with frequency of 25 each on the applied scale, while item B9 shows the highest frequency at scale is applied with 68.6 percent and frequency of 24. The highest frequency of item B10 is on the applied scale of $71.4 \%$ with 25 
frequency recorded, while the item B11 also has a frequency of only 25 respondents ie $71.4 \%$ of entrepreneurship co-curriculum students at UTHM are on applied scale. For items B12 shows that there is a frequency of $60.0 \%$ with the frequency of 21 being on the applied scale. Researchers conclude that there is an application of the element of ability to identify problem solving through entrepreneurship co-curriculum at UTHM.

\begin{tabular}{|c|c|c|c|c|c|c|c|c|c|}
\hline Item & $\begin{array}{|lll|}\begin{array}{l}\text { Ability to execute } \\
\text { results }\end{array} & \\
\end{array}$ & & 1 & 2 & 3 & 4 & 5 & $\begin{array}{l}\text { Mean } \\
\text { score }\end{array}$ & $\begin{array}{l}\text { Interpretation } \\
\text { mean }\end{array}$ \\
\hline B13 & $\begin{array}{l}\text { I am able to solve the } \\
\text { problem using the best } \\
\text { alternative. }\end{array}$ & $\begin{array}{l}\mathrm{F} \\
\%\end{array}$ & - & - & $\begin{array}{l}5 \\
14.3 \\
\end{array}$ & $\begin{array}{l}25 \\
71.4 \\
\end{array}$ & $\begin{array}{l}5 \\
14.3 \\
\end{array}$ & 4.00 & High \\
\hline B14 & $\begin{array}{l}\text { I was motivated to } \\
\text { solve the problem. }\end{array}$ & $\%$ & - & $\begin{array}{l}1 \\
2.9\end{array}$ & $\begin{array}{l}1 \\
2.9\end{array}$ & $\begin{array}{l}23 \\
65.7\end{array}$ & $\begin{array}{l}10 \\
28.6\end{array}$ & 4.20 & High \\
\hline B15 & $\begin{array}{l}\text { I am responsible for } \\
\text { every decision made } \\
\text { to achieve my goals. }\end{array}$ & $\begin{array}{l}\% \\
\mathrm{~F}\end{array}$ & - & - & - & $\begin{array}{l}22 \\
62.9\end{array}$ & $\begin{array}{l}13 \\
37.1 \\
\end{array}$ & 4.37 & High \\
\hline
\end{tabular}

The findings of table 4 show the analysis of the fourth element of abilities to carry out the results for the highest B13 percentage items is on the applied scale of $71.4 \%$ with a frequency of 25 and another $14.3 \%$ respectively with a frequency of 5 at a less-applied scale and highly applied. While the highest percentage of item B14 is $65.7 \%$ with frequency of 23 at scale applied. Whereas item B15 obtained 62.9 with frequency of 22 at applied scale. The researcher concludes that there is an application of the element in the ability to implement through the entrepreneurship co-curriculum at UTHM. The mean score analysis, frequency and percentage of the questionnaire above shows that the four elements are applied through the entrepreneurship co-curriculum at UTHM. Therefore, the researchers conclude that there is an application to the problem solving skills based on the analysis of the questionnaire.

\section{Discussion}

The discussion on the first question covers four elements of problem solving skills through the studied entrepreneurship co-curriculum ie the element of ability to identify and analyze problems, collect data and decisionmaking ability, ability to identify problem solving and ability to execute decisions.

The result of the analysis from the findings on the application of problem solving skills through entrepreneurship co-curriculum based on the four instruments underlying the findings of the study were document analysis, observation checklist analysis, interviews transcript analysis and questionnaire analysis. The researcher concludes that there is an application to the elements of problem solving skills through entrepreneurship cocurriculum among UTHM students section 7. However, these elements of skill are applied to a high level. The findings of this study are in line with Deborah's opinion (2007), indicating the number of programs or activities undertaken at universities have significant relationships with unhealthy social symptoms. Hence diversification in the implementation of co-curricular activities is important to provide greater opportunities for engagement among students and consequently benefit from them. According to Badusah et al. (2009), co-curriculum in IPT is complementary to the core curriculum curriculum cycle.

The researcher's findings also conform to the formulas that have been carried out by Rahim (2004), pure values need to be nurtured through the educational process to form strong, moral, capable people to face challenges and capable of solving the conflict and crisis faced. This is also supported by Jalil (2012) in their study of participating in co-curricular activities conducted at IPT such as through community service co-curricular, students can improve soft skills such as problem solving skills among students can be applied.

This is clearly contradictory to the opinion of Rubin et al. (2002) that there are some outdoor activities that waste time of students where there are activities that do not support the subject of learning in the classroom. The findings of the study also denied the findings of the study conducted by Yahaya et al. (2010) the co-curricular activities at Technical Secondary School were less emphasized and only relieved cough on the stairs. After all this co-curricular activity is considered to be a waste of time and is only carried out when free of time without regard to the objective of its existence. Many students assume co-curricular activities are not important and are wasting time because they are not assessed as academically relevant activities.

In terms of significance, through this study, the researcher sees that the problem solving skills should be important to be applied to the students and that the aspirations can be implemented well through the involvement of students through entrepreneurship co-curriculum. Opinions that say co-curricular activities are just a waste of time students are very irrelevant. This is because the curriculum based on the Teaching and Learning Plan (RPP) applied in every activity conducted by entrepreneurship co-curriculum should help students to improve their soft skills (KI) in particular problem solving skills. This is in line with Sunday's (2012) opinion on the activities conducted through this soccer game to contribute to the development of interpersonal skills among students. 


\section{Conclusion}

Throughout the analysis process of all the research instruments, the researcher found that other elements of the same KI were also applied through entrepreneurship co-curriculum. Among the elements of KI are leadership skills and teamwork skills that should necessarily have to produce a caliber and quality student. In conclusion, based on the findings of this study, the researcher concluded that the co-curricular activities carried out by the entrepreneurship co-curriculum at UTHM directly involving the semester 1 session of 2012/2013 in these organized activities are in line with the wishes of the KPT to implement KI in particular the problem solving skills among Malaysian IPT students. The effort is to pursue the country's mission and vision towards globalization to compete overseas.

\section{Acknowledgement}

a) University of Tun Hussein Onn Malaysia

b) Research, Innovation, Commercialization \& Consultancy Office.

c) Fundamental Research Grant Scheme (FRGS) under Vote 1638.

\section{References}

ACNielsen, R. S. (2000). Employer Satisfaction With Graduate Skills Research Report. Department of Education, Training and Youth Affairs. Commonwealth of Australia.

Badusah, J., Hashim, R. A., Konting, M. M., Suandi, T., Salih, M. and Yusof, N. (2009). Pembangunan Pelajar: Memperkasakan Kokurikulum Institusi Pengajian Tinggi. Universiti Putra Malaysia: Serdang.

Buntat, Y., Saud, M. S. and Hussain, H. A. (2008). Cabaran Politeknik Sultan Ahmad Shah (Polisas) Membangunkan Modal Insan Sejajar Dengan Keperluan Sektor Industri. Fakulti pendidikan UTM.

Jalil, N. A. A. (2012). Pembangunan Kemahiran Menyelesaikan Masalah Menerusi

Mohamad, A. M., Harun, J. and Aris, B. (2009). Kelemahan Penguasaan Kemahiran Di Kalangan Pelajar Pedagogi Dan Teknologi Sebagai Pendekatan Penyelesaian. . Fakulti Pendidikan. UTM.

Pauw, K. and Osthuizen, M. (2008). Graduate Unemployment In The Face Of Skills Shortage : A Labour Market Paradox. Economics, 76(1): 45-57

Rahim, A. A. A. (2004). Pengurusan Gerak Kerja Kokurikulum. Selangor: Penerbit Oxford Sdn. Bhd.

Rubin, R. S., Bommer, W. H. and Baldwin, T. T. (2002). Using extracurricular activity as an indicator on interpersonal skill: Prudent evaluation or recruiting malpractice?. Human Resource Management, Winter 2002, 41(4): 441-54. Available: http://collegiateassessment.com/acarticle2.pdf.

Yahaya, A., Hashim, S. and Muthalib, Y. A. (2010). Keberkesanan Aktiviti Kokurikulum (Sukan) : Perbandingan di antara Sekolah Menengah Teknik dan Sekolah Menengah Akademik Harian. Universiti Teknologi Malaysia.

Zakariya, Z. (2003). Kesediaan institusi pendidikan tinggi awam dalam melahirkan pekerja berasaskan pengetahuan (K-Pekerja) : satu kajian kes di Universiti Teknologi Malaysia. 